\title{
Penggunaan Daun Lamtoro Sebagai Pakan Untuk Penggemukan Sapi Bali
}

\author{
Syamsul Hidayat Dilaga*, Muhamad Amin, Oscar Yanuarianto, Sofyan, dan Dahlanuddin \\ Fakultas Peternakan, Universitas Mataram, Mataram, Indonesia
}

\author{
Article history \\ Received: 07-02-2021 \\ Revised: 09-03-2021 \\ Accepted: 12-03-2021 \\ *Corresponding Author: \\ Syamsul Hidayat Dilaga, \\ Fakultas Peternakan, \\ Universitas Mataram, Mataram, \\ Indonesia;
}

Email: syamsulhdilaga@unram.ac.id
Abstract: Farmers are not used to giving leucaena leaves to the cattle they keep. This is because lack of information about benefits of leucaena is not widely known. Whereas leucaena leaves have high nutritional value and palatable. Cattle body weight can grow well, so farmers get an advantage when using leucaena as feed.Extension activity was conducted in Kelompok Tani Ternak Aik Kolong, Mura Village, District of Brang Ene, West Sumbawa Regency. Selection of places at the request of community leaders from this place. After the extension activities, farmers have begun to understand and realize that the maintenance cattle for fattening efforts absolutely need quality feed intake. Farmers will seed and a plant leucaena seed given in the cage area, yard, or in their fields after the rainy season arrives. This was conveyed in discussions (Q\&A) events that developed during extension activities and technical guidance conducted in a simulation. In the end of activities, the farmers still hope that this kind of activity is more often done, so that their skills and knowledge on how to raise cattle fattening can be applied in the Group in particular and in Mura Village-Brang Ene, West Sumbawa Regency generally.

Keywords: Leucaena; fattening; bali cattle

Abtrak: Peternak sapi penggemukan belum terbiasa memberikan daun lamtoro kepada sapi yang mereka pelihara. Hal ini karena informasi prihal manfaat lamtoro belum banyak diketahui. Padahal daun lamtoro mempunyai nilai nutrisi tinggi, sangat digemari oleh sapi. Bobot badan sapi dapat bertumbuh dengan baik, sehingga peternak mendapatkan keuntungan bila menggunakan lamtoro sebagai pakan sapinya. Penyuluhan dilakukan di Kelompok Tani Ternak Aik Kolong yang ada di Desa Mura Kecamatan Brang Ene Kabupaten Sumbawa Barat. Pemilihan tempat sesuai permintaan tokoh masyarakat di sana. Setelah usai kegiatan penyuluhan, peternak sudah mulai faham dan sadar bahwa pemeliharaan sapi untuk usaha penggemukan mutlak perlu asupan pakan bermutu. Mereka akan menyemaikan dan menanam bibit lamtoro yang diberikan di areal kandang, pekarangan rumah, maupun di ladang mereka setelah musim hujan tiba. Hal ini mereka sampaikan dalam acara diskusi/tanya jawab yang berkembang selama kegiatan penyuluhan maupun bimbingan teknis yang dilakukan secara simulasi. Mereka tetap berharap agar kegiatan semacam ini lebih sering dilakukan, agar keterampilan dan pengetahuan mereka tentang cara beternak sapi penggemukan yang baik dapat diterapkan di Kelompok Tani Ternak tersebut khususnya maupun di Desa Mura-Brang Ene, Kabupaten Sumbawa Barat umumnya.

Kata Kunci: lamtoro; penggemukan; sapi bali 


\section{PENDAHULUAN}

Pemeliharaan sapi bali oleh peternak di Kabupaten Sumbawa Barat masih dilepas bebas mencari pakan sendiri siang malam. Kalaupun mereka harus memberi pakan kepada ternaknya, maka hanya berupa rumput lapangan, ataupun aneka hijauan lainnya yang diambil di sawah maupun pinggir jalan, serta aneka limbah pertanian seperti jerami padi, jerami jagung, jerami kacang tanah, dan jerami kedele. Pakan tersebut tentu tidak mampu memenuhi kebutuhan ternak, karena memiliki nilai nutrisi yang rendah. Hal ini berakibat kepada produktivitas ternak yang dipelihara rendah.

Daun lamtoro merupakan jenis legum pohon yang mengandung nilai gizi tinggi. Penelitian kalangan pakar seperti dikutip Dilaga, dkk. (2017) bahwa, nilai nutrisi lamtoro protein kasar 22,036,8\% dan energi bruto 20,1 KJ/g. Panjaitan dkk, (2013), Dahlanuddin, dkk. (2014) melaporkan bahwa penggunaan daun lamtoro pada pakan sapi bali dewasa maupun pedet yang pakan basal rumput lapangan memberikan pertumbuhan lebih baik dibandingkan dengan hanya diberikan rumput lapangan. Hal ini tentu akan berdampak kepada efisiensi usaha mereka. Apalagi harga konsentrat yang merupakan sumber protein dan energi dipandang masih cukup mahal oleh peternak, sehingga salah satu alternatif penanggulangan kekurangan unsur nutrisi tersebut pada pakan sapi adalah dengan pemberian daun lamtoro.

Peternak di Desa Mura, Kecamatan Brang Ene, Kabupaten Sumbawa Barat umumnya memelihara sapi bali. Mereka sudah mulai melakukan usaha penggemukan terhadap sapi jantan. Adapun pakan yang diberikan $80 \%$ berasal dari hijauan. Mereka belum atau jarang sekali memberikan konsentrat karena harganya mahal. Padahal untuk usaha penggemukan aspek pakan mestinya diberikan sesuai kebutuhan, baik jumlah maupun mutunya (Dilaga, dkk, 2016).

Pakan mempengaruhi total keuntungan. Pakan yang baik, bermutu, dan diberikan sesuai jumlah yang dibutuhkan ternak sangat mempengaruhi keberhasilan bisnis penggemukan. Karena kalau pakan tidak sesuai dengan kebutuhan ternak, dapat dipastikan kegagalan akan terjadi pada aspek pertumbuhan ternak. Kegagalan pertumbuhan, menyebabkan kehilangan waktu, tenaga, dan biaya bagi usaha penggemukan. Besarnya kerugian akibat pertumbuhan berupa pertambahan bobot badan ditaksir menyumbang paling sedikit $60 \%$ panen sapi siap potong. Pemberian pakan pada sapi penggemukan sebaiknya memperhatikan beberapa hal seperti: 1) sapi diberi rumput dan legume secara ad libitum, dengan perbandingan 60:40,2) berikan pakan tambahan yang mempunyai kandungan protein kasar (PK) sekitar 14-16\% sebanyak 0,5-1,0 kg/ekor/hari, 3) air minum disediakan ad libitum, dan 4) berikan tambahan mineral $\mathrm{Ca}, \mathrm{P}, \mathrm{Zn}$, dan garam.

Berdasarkan uraian yang telah dikemukakan itu, maka dipandang perlu melakukan penyuluhan melalui pengabdian kepada masyarakat tentang penggunaan daun lamtoro sebagai pakan untuk penggemukan sapi yang mereka pelihara. Tegasnya, tujuan penyuluhan ini adalah memberikan informasi/pengetahuan tentang cara pemberian pakan yang mampu memberikan asupan nutrisi yang cukup baik untuk menghasilkan pertumbuhan yang cepat bagi sapi.

\section{METODE}

Kegiatan pengabdian pada masyarakat dilaksanakan di Kelompok Tani Ternak (KTT) Aik Kolong, Desa Mura, Kecamatan Brang Ene, Kabupaten Sumbawa Barat. Pelaksanaan penyuluhan menggunakan metode partisipatif dengan pendekatan dalam bentuk pendidikan dan keterampilan. Dilakukan ceramah, peragaan cara memilih biji lamtoro untuk benih, penyemaian biji, penanaman 
bibit, perawatan tanaman, dan penggunaan daun lamtoro untuk penggemukan sapi jantan, yang pelaksanaanya secara simulasi.

Evaluasi dilakukan dalam dua tahap yaitu a) dilaksanakan selama kegiatan penyuluhan/ ceramah meliputi kehadiran dan tanya jawab/diskusi yang mereka lakukan dan b) setelah kegiatan penyuluhan/ceramah meliputi keterampilan cara memilih biji untuk benih, penyemaian, penanaman, perawatan, dan penggunaan daun lamtoro untuk penggemukan sapi jantan.

\section{HASIL DAN PEMBAHASAN}

\section{A. Pelaksanaan Kegiatan}

Dalam pelaksanaan kegiatan pengabdian ini, kami didampingi oleh Drh. Moh. Adis Saramba selaku Field Officers Indobeef BPTP-NTB dan Dedy Supriadi S.Pt. petugas lapang ACIAR (Australian Centre for International Agricultural Reseach). Keduanya menangani pengembangan penanaman lamtoro taramba di Kabupaten Sumbawa Barat.

Pelaksanaan kegiatan dilakukan di Kelompok Tani Ternak (KTT) Aik Kolong Desa Mura Kecamatan Brang Ene Kabupaten Sumbawa Barat. Pemilihan tempat ditentukan berdasarkan aspirasi yang diminta/diinginkan oleh para peternak ke Pak Camat dan Petugas Dinas Peternakan Kecamatan, Eni Kusumawati, S.Pt., agar di lokasi mereka dilakukan penyuluhan tentang peternakan sapi terutama masalah pakan untuk sapi penggemukan.

Hadir dalam acara tersebut selain petugas dan pejabat yang telah disebutkan terdahulu, juga anggota KTT Aik Kolong, dan beberapa anggota masyarakat desa yang tertarik pada acara ini dan berencana untuk memelihara sapi.
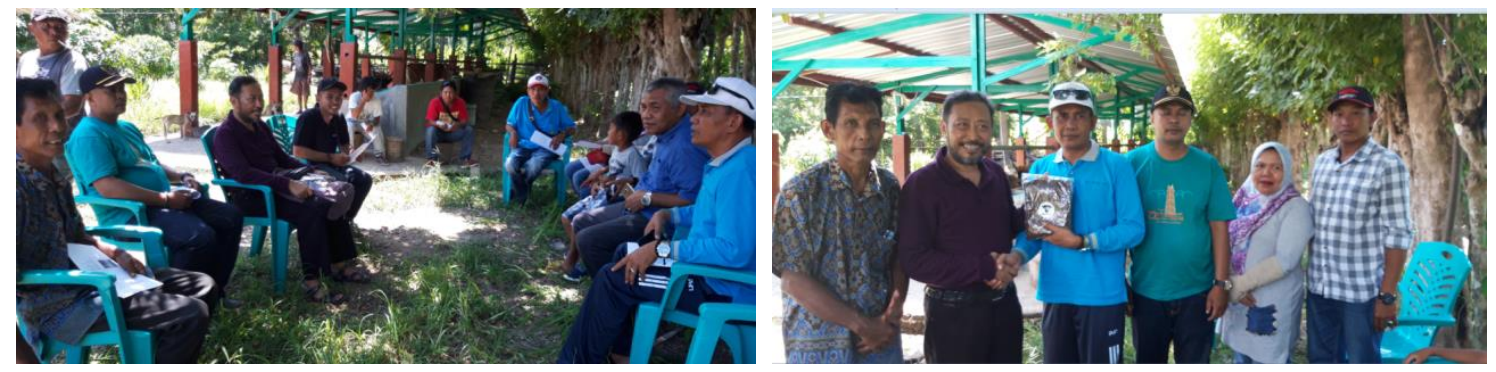

Gambar 1. Pelaksanaan Penyuluhan dan Penyerahan Biji Lamtoro Tarramba kepada Pak Camat dan perwakilan Kelompok Tani Ternak Aik Kolong Desa Mura Kecamatan Brang Ene Kabupaten Sumbawa Barat

Materi pengabdian meliputi pemilihan dan penyemaian biji, penanaman bibit, perawatan tanaman, dan pemberian daun lamtoro untuk sapai penggemukan.

Tanaman lamtoro pada dasarnya sedikit sekali membutuhkan perawatan, kecuali pada masa awal pertumbuhan, seperti penyiraman. Pada musim hujan tidak masalah, namun ketika musim kemarau, penyiraman dilakukan $2 \mathrm{x}$ sehari. Setelah tanaman berumur setahun, dapat dikatakan perawatan yang dibutuhkan sangat minimal, karena perakaran tanaman sudah kuat dan mampu menopang pertumbuhan batang, tidak perlu dilakukan pemupukan dan penyiraman, karena tanaman ini tahan kering.

Lamtoro hanya ditanam sekali saja, karena umur tanaman dapat mencapai 30 tahun. Panen perdana dapat dilakukan ketika tanaman berumur 1 (satu) tahun. Pemanenan berikutnya dilakukan setiap 2 (dua) bulan pada musim hujan dan 3 (tiga) bulan sekali pada musim kemarau untuk setiap 
pohon. Jumlah biomassa daun sekali panen berkisar antara 0,5-1,0 kg/pohon, bergantung kepada umur tanaman, musim, dan tingkat kesuburan lahan tempat tanaman tersebut tumbuh. Pemanenan/pemangkasan daun sebaiknya dilakukan pada posisi sekitar $120 \mathrm{~cm}$ di atas permukaan tanah. Dengan demikian pakan hijauan berkualitas tinggi dapat tersedia sepanjang tahun.

Perawatan tanaman yang perlu dilakukan adalah mencegah adanya kutu loncat yang merupakan hama utama tanaman ini. Kutu loncat menyerang tanaman lamtoro pada pertengahan sampai dengan akhir musim hujan. Siklus hidup kutu loncat mulai dari telur sampai dewasa sekitar 1020 hari. Adapun bagian yang diserang adalah tangkai, kuncup daun, tunas dan daun muda, sehingga pertumbuhan tanaman terhambat. Cara mencegah kutu loncat adalah melakukan penyemprotan insektisida berbahan aktif Dimethoda yang bersifat sistemik dan mampu bertahan selama 2-4 minggu. Saat penyemprotan pada pagi hari, ketika tanaman berumur 3 minggu, kemudian diulangi lagi pada saat berumur 3 bulan. Selain itu, di areal pertanaman lamtoro sering tumbuh gulma. Untuk mengatasi laju invasi gulma dilakukan dengan mengintegrasikan pertanaman lamtoro dengan aneka jenis rumput tanaman pakan, tanaman pangan dan hortikultura seperti jagung, padi lading, cabe, kedele, dan kacang tanah (Dilaga,dkk. 2017).

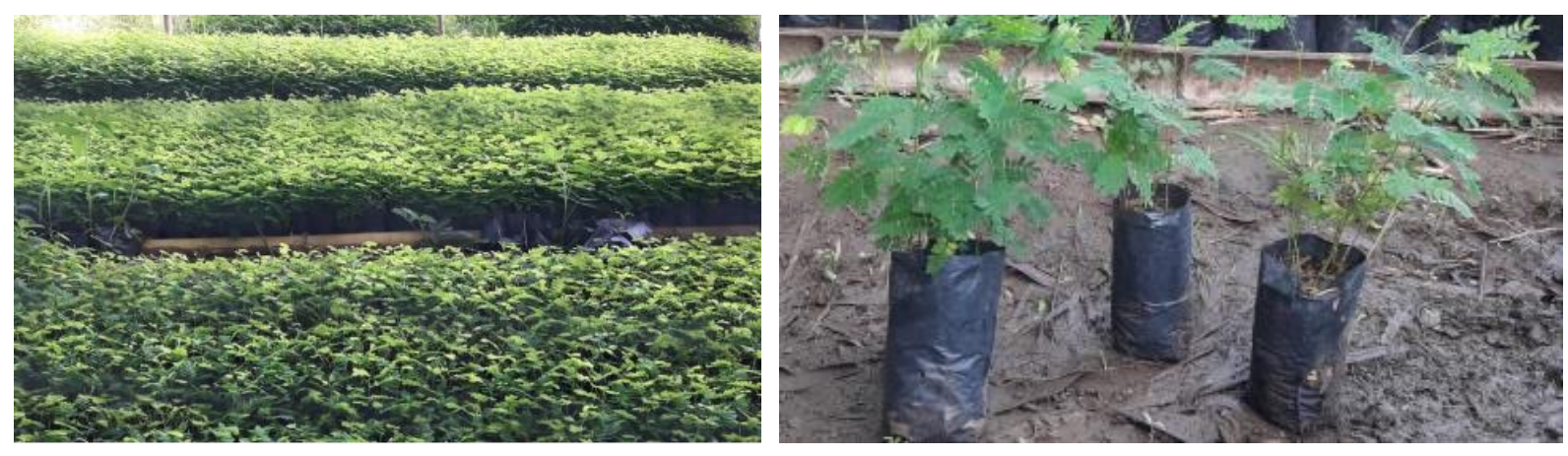

Gambar 2. Contoh Persemaian di bedengan dan kokeran.

Pemberian pakan daun lamtoro kepada sapi jantan akan mampu meningkatkan laju pertumbuhan sapi, serta memperpendek waktu yang diperlukan untuk mencapai bobot potong. Selain itu, dapat diketahui berapa jumlah pakan yang harus disediakan untuk memenuhi kebutuhan sapi penggemukan setiap saat. Keuntungan lain dari penanaman lamtoro tarramba ini adalah peternak dapat memberikan pakan bermutu tinggi kepada sapinya, dan efisiensi usaha meningkat karena menghemat waktu, tenaga, dan dana.

Adapun kriteria pakan berkualitas tinggi yang perlu dikembangkan adalah: 1) mengandung protein tinggi, minimal 20\%, 2) mudah dicerna, kecernaan di atas 60\%,3) produksi biomassa tinggi, 4) disukai oleh ternak, 5) mudah dikembangkan, dirawat, dan dipanen, 6) tidak memerlukan input mahal seperti pupuk, dan 7) tahan kering.

Salah satu pakan yang memenuhi syarat atau kriteria tersebut adalah leucaena $c v$ tarramba/lamtoro/belandingan/kawa manila (Dilaga, dkk. 2017). Namun di lain pihak, tanaman lamtoro belum banyak dibudidayakan oleh peternak di Pulau Sumbawa. Hal ini penting agar peternak dapat memaksimalkan produksi ternaknya melalui pemberian pakan bermutu. Adapun kandungan protein lamtoro adalah $18-30 \%$, sedangkan rumput 6-12\%. Demikian pula kecernaan lamtoro lebih baik yaitu $60-75 \%$ dibanding rumput $45-55 \%$. 
Sapi jantan yang kurang gizi sejak menyusui sampai periode pembesaran akan lambat mencapai bobot potong tinggi meskipun diberi pakan bermutu tinggi. Sapi jantan yang mendapatkan pakan bermutu tinggi sejak lepas sapih sampai umur sekitar 16 bulan memiliki laju pertumbuhan yang tinggi selama penggemukan dan menghasilkan bobot potong dalam waktu yang singkat (kurang dari 24 bulan).

\section{Penggunaan Daun Lamtoro Untuk Penggemukan Sapi Jantan}

Daun lamtoro dapat diberikan sebagai pakan tunggal (100\%) untuk sapi penggemukan tanpa menimbulkan pengaruh negatif pada pertumbuhan dan kesehatan. Namun pemberian $100 \%$ daun lamtoro dianggap pemborosan pakan sumber protein, sehingga harus dikombinasikan dengan sumber energi yang murah seperti rumput muda atau dedak padi. Proporsi optimal daun lamtoro dalam ransum sekitar $60 \%$. Sisanya bisa berupa rumput dan/atau limbah pertanian seperti jerami jagung, atau limbah industri yang kaya energi seperti dedak padi. Lamtoro sebaiknya dicacah pendek $(15-20 \mathrm{~cm}$ agar tidak banyak yang terbuang.

Adapun jumlah pohon lamtoro yang harus ditanam untuk menyediakan pakan yang cukup untuk sapi tergantung pada: 1) Musim (musim hujan vs musim kemarau), 2) Umur tanaman, dan 3) Kesuburan tanah.

Perhitungan sederhana untuk jumlah pakan yang berbeda untuk memberi makan seekor sapi dengan bobot badan $200 \mathrm{~kg}$.

- Seekor sapi dengan bobot $200 \mathrm{~kg}$ memerlukan pakan segar sebanyak $12 \%$ dari bobot badan= $12 / 100 \times 200=24 \mathrm{~kg}$ per hari. Legume pohon sebaiknya diberikan maksimal $60 \%$ dari ransum, sisanya berupa rumput segar dan pakan lain. Sapi dengan bobot badan $200 \mathrm{~kg}$ memerlukan $60 \%$ x $24 \mathrm{~kg}=14,4 \mathrm{~kg}$ lamtoro atau turi per hari dan rumput segar atau pakan lain $=40 \%$ x $24 \mathrm{~kg}=9,6 \mathrm{~kg}$ per hari

- Jumlah pohon lamtoro atau turi yang diperlukan setiap hari:

- Satu pohon lamtoro menghasilkan $4 \mathrm{~kg}$ hijauan segar per panen, jadi untuk mendapatkan 14,4 $\mathrm{kg}$ diperlukan 4 pohon per hari

- Lamtoro dapat dipanen sekitar 2,5 bulan (75 hari), sehingga jumlah lamtoro yang harus ditanam untuk satu ekor sapi adalah $75 \times 4$ pohon $=300$ pohon.

\section{Perhitungan sederhana untuk jumlah pakan yang berbeda untuk memberi makan seekor sapi dengan bobot badan $200 \mathrm{~kg}$.}

- Seekor sapi dengan bobot $200 \mathrm{~kg}$ memerlukan pakan segar sebanyak $12 \%$ dari bobot badan= $12 / 100 \times 200=24 \mathrm{~kg}$ per hari

- Legume pohon sebaiknya diberikan maksimal $60 \%$ dari ransum, sisanya berupa rumput segar dan pakan lain. Sapi dengan bobot badan $200 \mathrm{~kg}$ memerlukan $60 \%$ x $24 \mathrm{~kg}=14,4 \mathrm{~kg}$ lamtoro atau turi per hari dan rumput segar atau pakan lain $=40 \% \times 24 \mathrm{~kg}=9,6 \mathrm{~kg}$ per hari

- Jumlah pohon lamtoro atau turi yang diperlukan setiap hari:

- Satu pohon lamtoro menghasilkan $4 \mathrm{~kg}$ hijauan segar per panen, jadi untuk mendapatkan 14,4 $\mathrm{kg}$ diperlukan 4 pohon per hari

- Lamtoro dapat dipanen setiap 2,5 bulan (75 hari), sehingga jumlah lamtoro yang harus ditanam untuk satu ekor sapi adalah $75 \times 4$ pohon $=300$ pohon. 


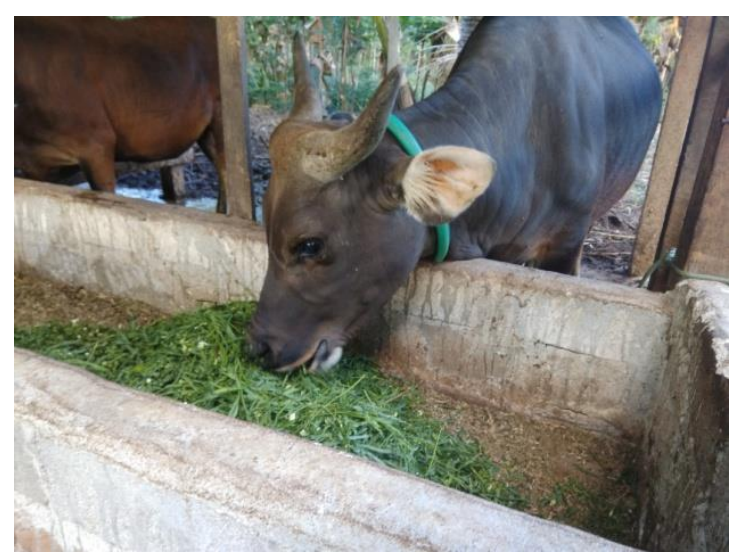

Gambar 3. Pemberian pakan daun lamtoro pada sapi penggemukan

\section{B. Diskusi}

Setelah pemaparan pengabdian selesai disampaikan oleh pemateri, kemudian dilakukan diskusi/tanya jawab.

Berikut ini adalah kutipannya.

\begin{tabular}{|c|c|c|}
\hline No & Penanya dan Pertanyaannya & Jawaban \\
\hline 1. & $\begin{array}{l}\text { Mulyadi: } \\
\text { Semua anggota kelompok tani } \\
\text { ternak (KTT) Aik Kolong adalah } \\
\text { petani. Kami berterimakasih diberi } \\
\text { biji lamtoro taramba untuk ditanam } \\
\text { di lahan kami yang nantinya } \\
\text { dijadikan sebagai sumber pakan } \\
\text { sapi kami pak. Sekali lagi terima } \\
\text { pak. }\end{array}$ & $\begin{array}{l}\text { Sama-sama pak. Kami juga berterima kasih atas } \\
\text { segala perhatian para peserta penyuluhan yang } \\
\text { sempat hadir memenuhi undangan kami. Padahal } \\
\text { bapak-bapak pasti punya kesibukan lainnya, yang } \\
\text { penting sekarang, mari kita focus menanam, } \\
\text { merawat, dan menggunakan lamtoro taramba untuk } \\
\text { penggemukan sapi yang bapak usahakan. }\end{array}$ \\
\hline 2. & $\begin{array}{l}\text { Arifin: } \\
\text { Apa kegunaan lain tanaman } \\
\text { lamtoro ini pak? }\end{array}$ & $\begin{array}{l}\text { Lamtoro dapat ditanam dipekarangan rumah } \\
\text { sebagai pagar hidup, ditanam di kebun, atau di } \\
\text { lahan tidur untuk dijadikan tanaman penghijauan. } \\
\text { Tanaman ini dapat di panen puluhan tahun } \\
\text { lamanya. Kayunya dapat dijadikan sebagai bahan } \\
\text { bakar/kayu api maupun bahan untuk bangunan serta } \\
\text { bahan mebel. }\end{array}$ \\
\hline 3. & $\begin{array}{l}\text { Haerudin: } \\
\text { Sapi saya tidak pernah diberi daun } \\
\text { lamtoro. Apakah pemberian } \\
\text { lamtoro tidak menyebabkan sapi } \\
\text { mencret? }\end{array}$ & $\begin{array}{l}\text { Kita mesti membiasakan/mengenalkan pakan baru } \\
\text { kepada ternak, dengan cara bertahap, sedikit demi } \\
\text { sedikit. Kalau sudah terbiasa, kemudian jumlah } \\
\text { pemberiannya diperbanyak. Untuk sapi jantan yang } \\
\text { digemukkan, daun lamtoro boleh diberikan } 100 \% \text {. } \\
\text { Pemberian lamtoro dapat dicampur dengan rumput } \\
\text { atau jerami, atau pakan yang biasa bapak berikan } \\
\text { kepada sapi, misalnya dedak, jagung giling. } \\
\text { Dengan cara seperti itu sapi tidak mencret. }\end{array}$ \\
\hline 4. & $\begin{array}{l}\text { M. Nurahman: } \\
\text { Apakah daun }\end{array}$ & $\begin{array}{l}\text { Boleh diberikan kepada sapi betina. Demikian pula } \\
\text { kepada bunting juga boleh diberikan, asalkan }\end{array}$ \\
\hline
\end{tabular}




\begin{tabular}{|c|c|c|}
\hline & diberikan kepada sapi betina? & $\begin{array}{l}\text { jangan dijadikan pakan tunggal alias pemberiannya } \\
\text { tidak boleh } 100 \% \text {, terutama pada } 3 \text { (tiga) bulan } \\
\text { terakhir menjelang beranak. Pemberian pakan daun } \\
\text { lamtoro kepada sapi betina bunting sebaiknya } 30 \% \\
\text { saja dari jumlah pakan yang diberikan. Misalnya } \\
\text { ibu bapak memberikan rumput segar } 50 \\
\text { kg/ekor/hari, maka daun lamtoro segar dapat } \\
\text { diberikan sekitar } 15 \mathrm{~kg} \text {. Dengan demikian, bobot } \\
\text { lahir pedet akan lebih tinggi, demikian pula dengan } \\
\text { produksi air susu akan meningkat. }\end{array}$ \\
\hline 5. & $\begin{array}{l}\text { Saraf: } \\
\text { Bagaimana cara pelihara sapi agar } \\
\text { cepat gemuk? }\end{array}$ & $\begin{array}{l}\text { Pilih bakalan yang bagus, badannya tinggi dan } \\
\text { panjang, sehat, hidungnya selalu kelihatan } \\
\text { basah/berkeringat, dan bulunya mengkilat. Pelihara } \\
\text { dan rawat secara baik. Keadaan kandang harus } \\
\text { bersih agar parasit dan sumber penyakit lainnya } \\
\text { dapat dicegah/dieliminir. Perhatikan makan dan } \\
\text { minumnya jangan sampai kekurangan. }\end{array}$ \\
\hline 6. & $\begin{array}{l}\text { Beberapa orang peserta penyuluhan } \\
\text { menyampaikan komentar (sambil } \\
\text { jalan): } \\
\text { kalau demikian kami akan cepat } \\
\text { menjual sapi asalkan diberi pakan } \\
\text { daun lamtoro. Karena gizinya } \\
\text { tinggi. Selain itu tenaga bisa } \\
\text { dihemat dibandingkan kalau } \\
\text { mencari rumput. Ibu-ibu bisa } \\
\text { mengerjakannya. Sekarang kami } \\
\text { faham pak. }\end{array}$ & $\begin{array}{l}\text { Syukur alhamdulillah kalau bapak-bapak mau } \\
\text { memberikan pakan daun lamtoro ini kepada sapi } \\
\text { yang bapak pelihara. Tenaga kita agak kurang } \\
\text { terkuras karena panen daun lamtoro lebih praktis, } \\
\text { kemudian bandan tidak terpapar langsung oleh sinar } \\
\text { matahari sebagaimana kalau mengarit rumput. Di } \\
\text { beberapa lokasi KTT di Kabupaten lain banyak ibu- } \\
\text { ibu yang mulai terjun memberi pakan daun lamtoro } \\
\text { kepada sapinya. Mereka senang melakukannya } \\
\text { karena tidak kepanasan oleh sinar matahari. Apalagi } \\
\text { jarak kebun tempat menanam lamtoro dekat dengan } \\
\text { kendang sapinya. }\end{array}$ \\
\hline
\end{tabular}

\section{Evaluasi}

Pada saat pelaksanaan penyuluhan sedang berlangsung, dilakukan evaluasi tentang kehadiran peserta/anggota KTT Aik Kolong dengan menugaskan seseorang untuk mencatat nama mereka. Seluruh peserta yang hadir berjumlah 19 orang, terdiri atas 15 orang anggota KTT Aik Kolong, dan 4 orang anggota masyarakat yang tertarik untuk beternak sapi. Selain itu, dilakukan pula pencatatan terhadap diskusi/ pertanyaan yang mereka kemukakan. Hasil evaluasi mendapatkan bahwa peserta penyuluhan sangat aktif dan bahkan setelah usai penyuluhan masih ada diantara mereka yang bertanya tentang masalah sapi dan pakannya.

Evaluasi berikutnya adalah meliputi keterampilan mereka dalam hal memilih biji untuk benih, penyemaian, penanaman, perawatan, dan penggunaan daun lamtoro untuk penggemukan sapi jantan, yang pelaksanaanya secara simulasi. Diperoleh hasil bahwa peserta penyuluhan cukup trampil dalam memilih dan menyemaikan biji lamtoro, menanam dan merawat tanaman, serta memberikan daun lamtoro untuk pakan sapi. Hal ini dapat difahami, karena selain memelihara sapi, mereka juga sebagai petani lahan kering. 


\section{KESIMPULAN DAN SARAN}

\section{Kesimpulan}

1. Perhatian dan semangat peserta mengikuti penyuluhan sangat besar. Terbukti dari kehadiran mereka dan diskusi yang disampaikan sangat kritis.

2. Penyuluhan/ceramah diikuti dengan tanya jawab dan latihan simulasi keterampilan dipandang dapat mempercepat pemahaman peternak akan pentingnya meningkatkan nilai gizi pakan sapi yang mereka pelihara.

3. Pemberian daun lamtoro sebagai pakan sapi untuk penggemukan sudah mulai difahami oleh peternak. Mereka akan menyemaikan dan menanam bibit lamtoro di areal kandang dan rumah mereka begitu musim hujan tiba.

\section{Saran}

Pendampingan secara berkelanjutan terhadap peternak dalam mengelola usaha peternakan sapi penggemukan perlu dilakukan secara berkesinambungan, terutama dalam pemberian pakan lamtoro, agar sapi yang mereka miliki dapat bertumbuh dan berkembang sesuai harapan.

\section{Ucapan Terima Kasih}

Ucapan terima kasih kami sampaikan kepada Bapak Camat, Petugas Dinas Peternakan Kecamatan Brang Ene, Kepala Desa Mura, seluruh Anggota KTT Aik Kolong dan masyarakat Desa Mura yang telah menerima kami dengan baik.

\section{DAFTAR PUSTAKA}

Dahlanuddin, O. Yanuarianto, D.P. Poppi, S.R. McLennon, and S.P Quigly. 2014. Live weight gain and feed intake of weaned bali cattle fed grass and tree legumes in West Nusa Tenggara, Indonesia. Anim. Prod. Sci. 54(7) pp: 915-921.

Dilaga, S.H., Imran, Santi Nururly, dan Padusung. 2016. Penanaman Lamtoro di Lar Milik Peternak Untuk Pakan Sapi Sumbawa Pasca Sapih Sebagai Penghasil Daging Dalam Menunjang Pariwisata. Prosiding Seminar Nasional Sainstek Ke-3 UNDANA Tahun 2016. Kupang, 2829 Oktober 2016. Hal: B-245-B-249.

Dilaga, S.H., Imran, Santi Nururly, dan Padusung. 2017. Lamtoro Sumber Pakan Potensial. Penerbit Pustaka Reka Cipta Bandung.

Panjaitan, T., M. Fauzan, Dahlanuddin, M.J. Halliday, and H.M. Shelton. 2013. Growth of bali bulls fattened with forage tree legumes in Eastern Indonesia: leucaena leucocephala in Sumbawa. Proc. of the $22^{\text {nd }}$ International Grassland Congress. Pp: 601-602.

Supriyadi, M., M.L.Mullik, Y.A.Sutaryono, C.D.C.Varela, L.Coimbra, P.D.Deus, and Dahlanuddin 2014. Tree legume-Maize-Cassava Integration to Improve Bali Cattle Production in Timor Leste. Proc. Aust. Soc. Anim. Prod. Vol. 30:146. 